\title{
Disaster Management of Dempo Volcano Eruption, Pagar Alam City - Indonesia Based on Local Wisdom
}

\author{
Erna Juita, Dedi Hermon, Eri Barlian, Indang Dewata, Iswandi Umar
}

\begin{abstract}
This research aims to identify various forms of local wisdom in disaster mitigation in the Dempo volcano eruption and determine the level of community understanding of local wisdom in disaster management. This research uses the descriptive explanative method. The analysis used is a combination of qualitative and quantitative descriptive analysis. The results of this study have identified several forms of local wisdom in disaster management in communities in the Dempo volcano. Cultural semiotics in the form of community advice and teachings, and the call to prayer when there is potential for eruption. Faunal semiotics in the form of the behaviour of various types of animals, vegetal semiotics in the condition of natural plants and cultivation, and physical semiotics in the form of natural signs. Public knowledge of local wisdom and disaster management is generally still low.
\end{abstract}

Keywords: dempo volcano, local wisdom, disaster, pagar alam.

\section{INTRODUCTION}

$\mathrm{D}$ saster mitigation is several activities to reduce disaster risk, both through physical development as well as awareness and increase the capacity of disaster threats [1-3]. Disaster mitigation is carried out on communities in disaster-prone areas [4-6]. Indonesia has a profile as one of the countries that have the most active volcanoes on earth [7, 8]. Volcanic eruptions that cannot be predicted correctly are correct, this requires that people who live on the slopes of the mountain must have the ability to respond to disasters if one day the mountain activity changes and increases[9].

In Indonesia, a volcano and the results of its processes in the form of rocks spread on land and at sea [7]. Based on geology, activities related to volcanoes in Indonesia have started since around 76 million years ago [7]. A volcano is a landscape of the earth's surface where magma material from

Revised Manuscript Received on May 15, 2020.

* Correspondence Author

Erna Juita*, Department of doctoral program of environmental science, Universitas Negeri Padang, Padang, Indonesi. Email: erna.pgri@gmail.com

Dedi Hermon, Department of geography and doctoral program of environmental science, Universitas Negeri Padang, Padang, Indonesia. Email: dihermon006@gmail.com

Eri Barlian, Department of doctoral program of environmental science, Universitas Negeri Padang, Padang, Indonesia. Email: eribarlian@unp.ac.id

Indang Dewata, Department of doctoral program of environmental science, Universitas Negeri Padang, Padang, Indonesia. Email: indangdewata@fmipa.unp.ac.id

Iswandi Umar, Department of geography and doctoral program of environmental science, Universitas Negeri Padang, Padang, Indonesia. Email: iswandi_u@yahoo.com

(C) The Authors. Published by Blue Eyes Intelligence Engineering and Sciences Publication (BEIESP). This is an open access article under the CC BY-NC-ND license (http://creativecommons.org/licenses/by-nc-nd/4.0/) inside the earth comes out or has already come out in the past, usually forming a mountain, more or less conical in shape with a crater at the top[10,11]. Volcano in Indonesia most of the formation process comes from the process of subduction zones between the Eurasian Plate and the Indo-Australian plate [12]. Indonesia has 127 active volcanoes with around 5 million residents residing in the vicinity [13].

Volcanoes in Indonesia are part of the Pacific Ring of Fire [14]. One area that has many volcanoes is the Sundanese arc [15]. Sunda Arc is a chain of volcanoes located on the islands of Sumatra, Java and the Nusa Tenggara islands [11]. On the island of Sumatra, mountain ranges are called the Bukit Barisan. This mountain range stretches to $1,700 \mathrm{~km}$ [5]. One of the volcanoes in Sumatra is Dempo Volcano [16]. Dempo Volcano is located on the border between South Sumatra Province and Bengkulu Province [17]. Historically, Dempo Volcano erupted in October 1994 on a scale of 1 Volcanic Explosive Index (VEI) [18].

When onetime Dempo Volcano erupted, this mountain has a high potential for disaster, the area around the volcano is occupied by many residents [9]. Various relics of past societies that were found indicate at least there has been a village since ancient times that continued for generations [19]. A large number of inhabitants in this region is due to the attractive factor in the form of natural resource potential, mainly due to the fertility of the land [1].

Risk reduction activities are part of disaster management [12]. Disaster management is important to minimize losses and damage caused by disasters [20]. This effort can be done by reducing the level of threat and vulnerability of the community and increasing/strengthening the capacity of the community to have disaster resilience [21]. Disaster management efforts through community capacity building cannot be separated from the identification of local wisdom of the community in dealing with volcanic eruptions [22]. Local wisdom is the local knowledge of the community which has been passed down from generation to generation [23]. This identification is an important first step in measuring community capacity in dealing with volcanic eruptions, to realize community-based disaster mitigation [10]. Talking about local wisdom will often be associated with local communities and with varying understandings [24]. Local wisdom is local ideas that are wise, full of wisdom, the good value that is embedded and followed by members of the community [12]. Being a way of life and knowledge as well as various life strategies in the form of activities carried out by local communities [15]. Local wisdom can answer various problems in meeting their needs [25]. The system of meeting their needs must encompass all elements of life [26].

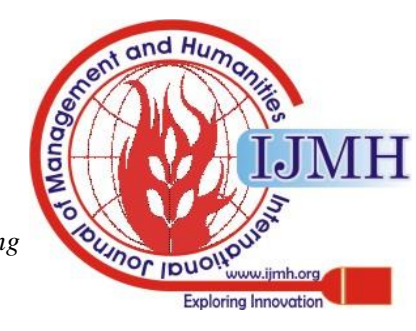


The elements of life which consist of religion, science, economics, technology, social organization, language and communication, and art [27].

Local wisdom is a traditional view and knowledge that is a reference in behaviour and has been practised for generations $[4,28]$. Local wisdom serves to meet the needs and challenges in the life of a community. Local wisdom functions and is meaningful in the community, both in the preservation of natural and human resources, preservation of customs and culture, as well as being beneficial to life [29]. When the community's understanding of the environment is good, disaster management concerning the characteristics of the two interactions can be more effective if implemented [30]. In connection with this goal, existing local wisdom needs to be explored and conveyed to be understood by future generations [23].

Besides being able to be applied in disaster mitigation systems, local wisdom is a wealth that needs to be maintained the people in Indonesia that are closely related to the environment to give special characteristics [14]. But at this time, information about the local wisdom of the community to cut off the spread of knowledge to the younger generation [27]. The activity of knowing and analyzing local wisdom related to disaster management is very useful, the benefit is to explore and identify the wealth of the socio-cultural system

\section{RESEARCH METHODS}

This research is explanatory descriptive research [33, 34]. Descriptive methods have been used to explain the symptoms encountered in detail. Descriptive methods have been combined with explanatory methods, which have tried to uncover the causes and effects that arise empirically in the field. This research has been carried out with a geographic approach that is an ecological approach where local wisdom as a problem to be studied is formed from the results of interactions between humans and the physical environment [30].

The population of this research is the entire community in the western slope area of Dempo Volcano, Pagar Alam City. Sampling has been done by purposive sampling. Samples have been selected from community leaders as respondents. Meanwhile, to obtain data on the level of understanding of the community, especially the younger generation regarding local wisdom in disaster mitigation, samples have been selected from community members aged 17-40 years.

The data that has been collected is qualitative data relating to local wisdom, in the form of advice, life philosophy, proverbs, teachings, animal behaviour, including regional toponymy; as well as quantitative data regarding people's understanding of local wisdom whose variables are influenced by age, level of education, occupation, and other social-population aspects. Data collection has been carried out by interviewing techniques, literature study, documentation, and observation.

Analysis has been done with a combination of qualitative and quantitative descriptive analysis [35]. Qualitative analysis has been done with inductive-deductive reasoning [31]. Local wisdom shows the social and cultural systems of to live side by side with nature in disaster-prone areas began of the community [32].

and interpretation of the presentation, not in the form of maps or tables. To provide an interpretation of local wisdom, qualitative analysis has been supported by interpretations that refer to the hermeneutic and semiotic approach to disaster [36]. As for hermeneutic analysis, the interpretation of the meaning contained behind the signs (especially cultural semiotics in the form of advice) must avoid subjective interpretations. Therefore in disaster hermeneutics, it is based on contextual background knowledge.

The basis of knowledge that has been used is geomorphology [37]. So the disaster semiotics approach used is geomorphological hermeneutics [38]. Disaster semiotics has identified various forms of intelligence that are compatible with natural semiotics (faunal semiotics, vegetal semiotics and physical semiotics) and cultural semiotics (normative semiotics and social semiotics) [36]. Semiotic analysis is supported by phenology and phenomenology [34]. Phenology is the study of the influence of climate or the surrounding environment on the appearance of organisms or populations, whereas phenomenology is the science of phenomena, which refers to "the visible". In the semiological analysis, there is a dichotomy of markers and markers. While the semiotic analysis includes trichotomy of icons, indexes and symbols [39]. As for hermeneutic analysis, the interpretation of the meaning contained behind the signs (especially cultural semiotics in the form of advice) must avoid subjective interpretations [38]. To answer the second problem, quantitative descriptive analysis is used.

\section{RESULT AND DISCUSSION}

This research was conducted in the Dempo Volcano, South Pagar Alam Selatan Sub-district, Pagar Alam City - South Sumatra Province. This Sub-district has 6 Villages. Dempo Urban Village has an area of 1,975 ha and a population of 2,428 with 650 families. The most widely used land is protected forest and community plantations as well as state plantations.

The results of this study have identified, discovered and recognized several forms of local wisdom in volcanic disaster mitigation, in the community. The local wisdom uses an analytic and descriptive semiotic perspective [40]. [4] explain descriptive semiotics in the form of teachings or advice from previous generations regarding the signs of an eruption disaster and its handling. Faunal semiotics in the form of animal behaviour that is understood and informed from generation to generation in society. The general public has understood that before the catastrophic eruption, animals from Dempo Volcano will descend away from the source of danger until it reaches a community settlement or agricultural area. However, there are variations in wisdom regarding the behaviour of these animals. Wisdom found in several villages shows that symptoms of descent from Dempo Volcano form certain groups and sometimes there are certain types of animals that are not normally found when Dempo Volcano has a normal status. The fall of these animals is a marker, while the eruption that will occur is a sign. [42] adds there is a causal relationship between animals that descend away from Dempo Volcano with an eruption.

Published By:

Blue Eyes Intelligence Engineering

\& Sciences Publication

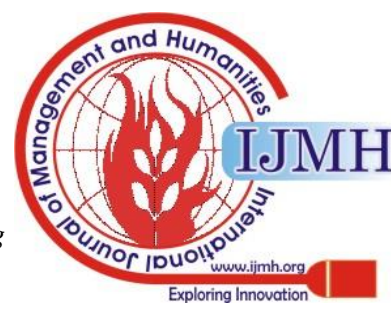


This is based on the condition of the physical environment in the mountain area not in a pretty good condition the same as when the status of the mountain is still normal.

Before the eruption, the community was able to estimate based on hotter temperatures compared to normal days, a roar could be heard from the direction of the mountain. In addition to the introduction of general signs, there is also the recognition of specific signs that are only found in one of the villages in the study area, which is reduced spring discharge. The condition of the physical environment is a marker while eruptions will occur as a sign. Physical environmental conditions are also related to cause and effect to the eruption [43]. For example, the thunderous sound like lightning accompanied by tremors in the mountain region is inseparable from the process of rising magma towards the lava crater. Earthquake tremors can disrupt the rock layers, causing the surface of the spring to be affected by the amount of water.

The condition of plants, especially community crops, is used as a marker of an eruption in the concept of vegetal semiotics. Recognition of the signs of the characteristics of this plant is not often found in the study area. Symptoms that are found include certain types of plant pests, as well as plants that die from dry or withered [44]. Cultural semiotics is found in the form of advice which is often told with the addition of certain myths. Cultural semiotics is very difficult to explore because there is still a lack of understanding of the community and not taught to every young generation. This strong allegation occurs because the advice or saying that contains myths is relatively difficult to be accepted by the community, but one of the cultural semiotics that is also associated with religious rituals is to echo the call to prayer when a volcanic eruption occurs. The call to prayer was interpreted as to invite and make every resident aware that everything that happened was due to the creator.

Another form of cultural semiotics found in Dempo Sub-district is the arrangement of the spatial area that forms certain patterns. In this Village, residential buildings are placed facing the road and clustering patterns, to facilitate the process of evacuation and information exchange between residents regarding volcanic activity during eruptions.

Physical and faunal semiotics still exist in the Dempo sub-district but have relatively little significance about disaster management. The form of physical semiotics that is still recognized is that the temperature of the air is felt to be rising before an eruption occurs, while the faunal semiotics in the form of animals originating from Mount Dempo descends into community settlements. There are various types of animals, including several species of birds that are rarely found flying in this village. Local wisdom in the form of advice at this time has begun to develop a lot with the background of the Islamic religion.

Various forms of local wisdom using a semiotic perspective have been found in the management of the Dempo Volcano fire disaster. Local wisdom is not well understood by some residents. Based on the analysis of data from respondents in the study area, only $32.32 \%$ of respondents understood that there was local wisdom, 36.73\% knew local wisdom but did not fully understand it and generally only heard from older members of the community. As many as $30.95 \%$ of other respondents did not understand the existence of local wisdom and its meaning in disaster management, even though it was only at a level that was never known.

Of the $32.32 \%$ of respondents who understood local wisdom, generally, the only forms understood were faunal semiotics and physical semiotics. Society better understands the signs of animal behaviour tends to often be a topic of discussion in the community. The form of faunal semiotics that is understood is still limited to understanding when there are animals that descend and move away from the peak area and the upper slopes of the volcano. This is understood as a sign of an eruption. In general, the respondents understood these signs but had never encountered them directly. Respondents who understand only get information based on stories from previous people. At this time signs of an eruption from animal behaviour are increasingly rare.

Unlike the faunal semiotics, physical semiotics are still felt immediately when an eruption disaster will occur. The physical form of semiotics that is understood is the rising temperature of the air which is getting hotter and the thunderous sound like thunder from the direction of the mountain. Physical environmental conditions such as temperatures getting hotter and the roar from the direction of the mountain is a symptom that occurs a lot and is felt immediately before an eruption. However, these signs in some cases are still ignored by the younger population due to lack of understanding and knowledge. Although the condition of the physical environment is felt by itself directly often it is not yet realized and understood.

Another form of local wisdom that is based on vegetal semiotics is not widely understood by the younger generation. Signs derived from plant and plant conditions are symptoms that are very rarely found and are not widely discussed in the community so they are not recognized and understood by young people.

The knowledge and understanding of young people about local wisdom in the study area are related to the age of the respondent and level of education. From the number of respondents who knew and understood local wisdom, aged between 30-40 years, no respondent understood local wisdom in the age group of 20-30 years. Understanding in older age groups can occur because of the experience of dealing with more eruptive disasters. This is because the narrative of the parents usually coincides with the eruption disaster. As for when there was no eruption, there was very little talk relating to actions to deal with the eruption disaster. About the level of education, respondents who know and understand local wisdom generally have the latest education at a high school level or higher.

The obstacle faced in maintaining local wisdom in the younger generation is the lack of teaching from previous generations, teaching for generations. At present, an in-depth understanding of local wisdom in dealing with eruption disasters is still limited to community leaders or older community members.

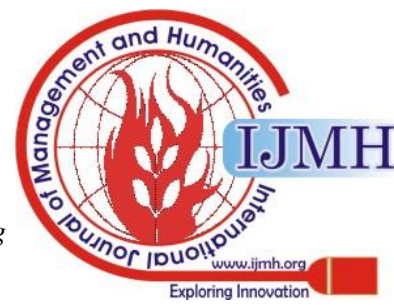




\section{CONCLUSION}

In the Dempo Volcano area, especially in Dempo Village, there are various forms of local wisdom about eruption disaster mitigation. using a semiotic perspective found some local wisdom. between the presence of understanding and knowledge obtained from community advice and guidance, understanding and knowledge of animal behaviour, understanding of natural vegetation and cultivation conditions and understanding of physical environmental conditions. There are differences in the results of an analysis of the level of knowledge and understanding of local wisdom based on age and education level. the more mature age, the better level of understanding and knowledge. the higher the level of education, the higher the level of understanding and knowledge.

\section{ACKNOWLEDGEMENT}

This research can be carried out smoothly, because of the help and cooperation of various parties. Therefore, the author would like to thank the analysis staff in Geography STKIP PGRI West Sumatera, the help for data analysis, to the Postgraduate Environmental Sciences UNP who has provided the opportunity and time to sharpen the academic abilities of us, especially in the field of environmental science.

\section{REFERENCES}

1. A. R. Suprapto, R. Nurmasari, Kehidupan Masyarakat Di Hunian Tetap Pasca letusan Gunung Merapi 2010. J. Dialog Penanggulangan Bencana, Vol. 7, Issue. 2, 2016

2. J. Maknun, Pembelajaran Mitigasi Bencana Berorientasi Kearifan Lokal pada Pelajaran IPA di Sekolah Menengah Kejuruan. Vol. 5, Issue. 2, pp.143-156, 2015

3. D. Hermon, Erianjoni, I. Dewata. A. Putra and O. Oktorie. Liquefaction Vulnerability Analysis as a Coastal Spatial Planning Concept in Pariaman City-Indonesia. International Journal of Recent Technology and Engineering (IJRTE). Vol. 8. Issue 2. pp. 4181-4186. 2019

4. S. S. W. Ernawati and E. P. Azrai, Hubungan Persepsi Kearifan Lokal Dengan Sikap Konservasi Masyarakat Desa Lencoh Kecamatan Selo Di Taman Nasional Gunung Merapi. Biosferjpb, Vol. 9, Issue. 1, pp.65-69, 2016

5. E. M. Nagari, Science and technology for the Alert Group Disaster ' Tumik Singgalang' Science and technology for the Alert Group Disaster "Tumik Singgalang" East Malalak Nagari, Malalak District , Agam Regency, West Sumatra. 2019

6. I.U.T. Novita, Community Perceptions of Disaster Recovery Program after the February 2019 Earthquake in Sangir Balai Janggo District , Solok, Sumatra J. Disaster, Geogr. Geogr. Educ., Vol. 3, Issue. 1, pp. 36-41, 2019

7. I. Pratomo, Klasifikasi gunung api aktif Indonesia, studi kasus dari beberapa letusan gunung api dalam sejarah. Jurnal Geologi Indonesia. Vol. 1, Issue. 4, pp.209-227, 2006.

8. E. Barlian, N. Syah and A. Razak, Science and technology for the Alert District, Agam Regency, West Sumatra. IOP Conference Series: Earth and Environmental Science. Vol. 314, Issue. 1, p. 012036, 2019

9. N.H.R. As'ari, Kajian Nilai Kearifan Lokal Masyarakat Adat Kampung Naga Dalam Pengelolaan Lingkungan Berbasis Mitigasi Bencana. Prosiding Seminar Nasional Geografi Ums 2016 Upaya Pengurangan Risiko Bencana Terkait Perubahan Iklim, pp. 472-486, 2016

10. H. Naping and I. Musywirah, A strategy of local wisdom-based natural disaster management in coastal communities in Barru District. IOP Conference Series: Earth and Environmental Science. Vol. 235, Issue. 1, p. 012033.2019

11. K. J. W. Pacey and C.G. Macpherson, Durham Research Online, in Linear volcanic segments in the central Sunda Arc, Indonesia, identi?ed using Hough Transform analysis, Vol. 44, pp. 1-54, 2014

12. R. Afrian, J. Hariadi, B. Akob, and Z. R. Islami, Local Culture Inventory for Disaster Mitigation Learning. IOP Conference Series: Earth And Environmental Science Paper 412, pp.1-6, 2020 Group Disaster "Tumik Singgalang” East Malalak Nagari, Malalak

13. S. Richards, G. Lister and B. Kennett, A slab in depth: Three-dimensional geometry and evolution of the Indo-Australian plate, pp. 1-11, 2007

14. A. Cahyadi, Krisis Identitas, Putusnya Estafet Kearifan Lokal Dan Peningkatan Risiko Bencana. Pengelolaan Lingkungan Zamrud Khatulistiwa, pp. 114-118, 2013

15. B. Kusumasari and Q. Alam, Disaster Prevention and Management Emerald Article: Local wisdom-based disaster recovery model in Indonesia, Emerald, Vol. 21, Issue. 3, pp. 351-369, 2012

16. D. S. L. Ismaini, M. Lailati and Rustandi, Analisis komposisi dan keanekaragaman tumbuhan di Gunung Dempo, Sumatera Selatan, Masyarakat Biodiversiti Indonesia, 2015, Vol. 1, no. 76, pp. 1397-1402

17. M. M.Muhaimin and I.W. Hidayat, Eksplorasi tumbuhan dan studi komposisi vegetasi di zona bukit dari Plants exploration and vegetation composition study in hill zone of Mount Patah , Bengkulu, Masyarakat Biodiversiti Indonesia, vol. 2, pp. 132-137, 2016

18. C. Newhall, S. Self and A. Robock, Anticipating future Volcanic Explosivity Index (VEI) 7 eruptions and their chilling impacts, Vol. 14, Issue. 2, pp.572-603, 2018

19. D. Wardyaningrum, Perubahan Komunikasi Masyarakat Dalam Inovasi Mitigasi Bencana Di Wilayah Rawan Bencana Gunung Merapi, Aspikom, Vol. 2, Issue. 3, pp. 179-197, 2014

20. S. Andreastuti, A. Budianto and E. T. Paripurno, Integrating Social and Physical Perspectives of Mitigation Policy and Practice in Indonesia, Volcanology, pp. 307-320, 2018, 2017

21. C. J. Horwell and P. J. Baxter, The respiratory health hazards of volcanic ash : a review for volcanic risk mitigation, pp. 1-24, 2006

22. S. Andreastuti, E. Paripurno, H. Gunawan, A. Budianto, D. Syahbana, and J. Pallister, Character of community response to volcanic crises at Sinabung and Kelud volcanoes, J. Volcanol. Geotherm. Res., Vol. 382, pp. 298-310, 2019

23. I. W. Suastra, Balinese Local Wisdom and Their Implications in Science Education at School, Int. Res. J. Manag. IT Soc. Sci., Vol. 4, Issue. 2, pp. 48-57, 2017

24. M. R. Mungmachon, Knowledge and Local Wisdom: Community Treasure, Int. J. Humanit. Soc. Sci., Vol. 2, Issue. 13, pp. 174-181, 2012

25. G. Adilah and S. Saputra, Enhacing Local Wisdom Through Local Content Of Elementary School In Java , Indonesia, Proceeding of the Global Summit on Education, Vol. 2013, Issue, pp. 11-12, 2013

26. A. M. Albantani and A. Madkur, International Journal of Applied Linguistics \& English Literature Think Globally, Act Locally: The Strategy of Incorporating Local Wisdom in Foreign Language Teaching in Indonesia, Int. J. Appl. Linguist. English, Vol. 7, Issue. 2, pp. 1-8, 2018

27. A. A. Rahu, K. Hidayat, M. Ariyadi, and L. Hakim, Management of Kaleka ( Traditional Gardens ) in Dayak community in Kapuas, Central Kalimantan, Vol. 3, Issue. 3, pp. 205-210, 2014

28. Z. A. Haris, A. Irianto, and D. Hermon, Local wisdom of Aek Latong society for mitigation and adaptation of soil movement disaster in North Sumatra, Indonesia Local wisdom of Aek Latong society for mitigation and adaptation of soil movement disaster in North Sumatra , Indonesia, 2019

29. N. Waskitaningsih, Kearifan Lokal Masyarakat Sub-Sistem Drainase Bringin Dalam Menghadapi Banjir, J. Pembang. Wil. Kota, Vol. 8, Issue. 4, pp. 383-391, 2012

30. M. N. B. Prasojo, Konstruksi Sosial Masyarakat Terhadap Alam Gunung Merapi: Studi Kualitatif tentang Kearifan Lokal yang Berkembang di Desa Tlogolele Kecamatan Selo Kabupaten Boyolali Jurnal, J. Anal. Sosiol., Vol. 4, Issue. 2, pp. 31-46, 2015

31. O. Oktorie, D. Hermon, A. Syarief, and A. Putra, A Calculation and Compiling Models of Land Cover Quality Index 2019 uses the Geographic Information System in Pariaman City, West Sumatra Province, Indonesia, International Journal of Recent Technology and Engineering (IJRTE), Vol. 8, Issue. 3, pp. 6406-6411, 2019

32. M. Blicharska, Incorporating Social and Cultural Significance of Large Old Trees in Conservation Policy, Vol. 28, Issue. 6, pp. 1558-1567, 2014

33. I. Akhtar, Research Design, in Research in Social Science: Interdisciplinary Perspectives Research Design, Vol. 2, Issue. 1, pp. 68-84 , 2019

34. Sunarto, Pemaknaan filsafati kearifan lokal untuk adaptasi masyarakat terhadap ancaman bencana marin dan fluvial di lingkungan kepesisiran, Forum Geogr., Vol. 25, Issue. 1, pp. 1-16, 2011

35. C. List, Levels : descriptive, explanatory, and ontological, 2017.

Published By:

Blue Eyes Intelligence Engineering

\& Sciences Publication

Journal Website: www.ijmh.org

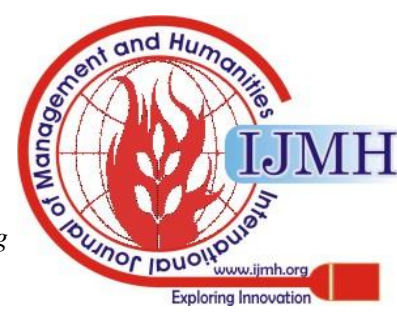


36. S. Setyawati, H. Pramono, A. Ashari, Kecerdasan Tradisional dalam Mitigasi Bencana Erupsi pada Masyarakat Lereng Baratdaya Gunungapi Merapi, Vol. 12, Issue. 2, pp. 100-110, 2015

37. A. Rezki, E. Juita, Dasrizal and A.Z.P. Ulni, Manajemen Data Spasial: Penggunaan Tanah Wilayah Pedesaan Di Sumatera Barat, Vol. 5, pp. 48-53, 2018

38. R. P. Santos, The Implementation Of Language, Literature, Art And Cultural Studies In Strengthening The Nation' S Civilization, International Seminar And Annual Meeting 2017 Fields Of Linguistics, Literature, Arts And Culture, pp. 1-5, 2017

39. F. Dezheng, Modeling Appraisal In Film : A Social Semiotic Approach, National University Of Singapore, 2012

40. H. Hajrah, R. Tang, S. Tahmir and K. Daeng, Reconceptualization of Local Wisdom through Kelong Makassar: A Semiotic Review of Michael Riffaterre. Journal of Language Teaching and Research, Vol. 10, Issue. 6, pp. 1209-1216, 2019

41. M.E Septiana, M.A.I. Wardoyo, N.Y. Praptiwi, A.N.S. Ashari, A. Ashari, N.I. Susanti and P.P. Nugrahagung, Disaster Education Through Local Knowledge in Some Area of Merapi Volcano. IOP Conference Series: Earth and Environmental Science, Vol. 271, issue. 1, p. 012011. 2019

42. D.A. Budd, V.R. Troll, D.R. Hilton, C. Freda, E.M. Jolis and S.A Halldorsson, Traversing nature's danger zone: getting up close with Sumatra's volcanoes. Geology Today, Vol.28, Issue. 2, pp. 64-70, 2012

43. D. Hermon, A. Putra and O. Oktorie, Characteristics of melanic epipedon based on biosequence in the physiography of Marapi-Singgalang, West Sumatra. IOP Conference Series: Earth and Environmental Science. Vol. 314, Issue. 1, pp. 012010, 2019

44. J.M. Prescott, P.A. Burnett, E.E. Saari, J.K.Ransom, J.D. Bowman, W. De Milliano and A.B. Geleta, Wheat diseases and pests: a guide for field identification, 1986

\section{AUTHORS PROFILE}

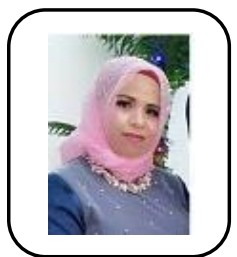

Erna Juita, is an obtained the Master Degree in Universitas Negeri Padang, 2017. He is actively involved in any researches regarded to disaster mitigation, local wisdom, environmental science and produces several scientific works in the form of SINTA-Indonesia indexed journals (ID: 260144). He is a chair the study program of Geography education STKIP PGRI West Sumatra and student doctoral program of Environmental Science, Universitas Negeri Padang.

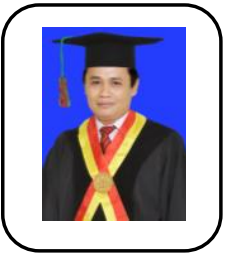

Dedi Hermon, is a Professor of Disaster Geography, obtained the Doctorate Degree in Doctor Program Natural Resources Management and Environment at Bogor Agriculture University (IPB) Indonesia, 2009. He is actively involved in any researches regarded to natural disaster, land cover, carbon stock and produces several scientific works in the form of Scopus indexed journals (ID 57200409691) and scientific books both national and international publications. He is assistant director of Postgraduate Universitas Negeri Padang as well as the head of Study Center of Disaster and Environment, Universitas Negeri Padang.

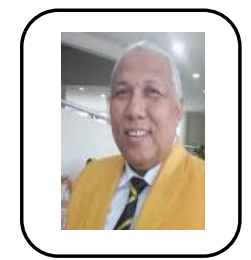

Eri Barlian, is a Professor of Environmenta Education, obtained the Doctorate Degree in Docto Program Education Science at Universitas Negeri Jakarta, 1999. He is actively involved in any researches regarded to environmental education, sports, recreation and disaster and produces several scientific works in the form of Scopus indexed journals (ID: 57202293479). He is Chair of Doctoral Program of Environmental Science, Universitas Negeri Padang.

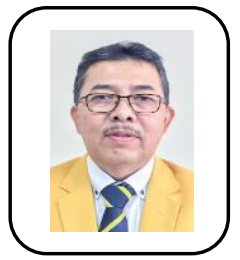

Indang Dewata, is an Associate professor of Environmental Science, obtained the Doctorate Degree in Doctor Program Education Science at Universitas Indonesia, 2009. He is actively involved in any researches regarded to environmental science, chemical and produces several scientific works in the form of Scopus indexed journals (ID: 57202287960) He is Chair of Masters Program of Environmental Science, Universitas Negeri Padang.

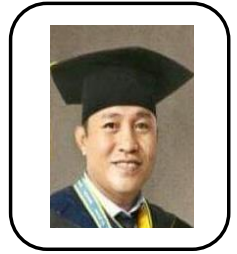

Iswandi Umar, is an Associate professor of Environmental Science, obtained the Doctorate Degree in Doctor Program Natural Resources Management and Environment at Bogor Agriculture University, 2015. He is actively involved in any researches regarded to environmental science, geography and produces several scientific works in the form of Scopus indexed journals (ID: 57204825796). He is Chair of Masters Program of Geography Education, Universitas Negeri Padang.Negeri Padang.

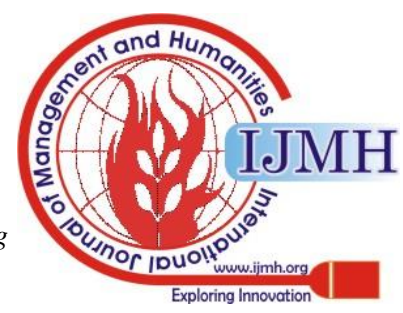

